\title{
Synthesis and Secretion of Corticosteroid-Binding Globulin by Rat Liver
}

\author{
A SOURCE OF HETEROGENEITY OF HEPATIC CORTICOSTEROID-BINDERS
}

\author{
JefFrey N. Weiser, Yung-Shun Do, and David Feldman, Department of Medicine, \\ Stanford University School of Medicine, Stanford, California 94305
}

A B S T R A C T Classical glucocorticoid receptors (type II) have a high affinity for synthetic and natural glucocorticoids. We have previously demonstrated an additional binding site in kidney cytosol (type III) which has a high affinity for corticosterone but a low affinity for dexamethasone. In many ways, this binder resembles plasma corticosteroid-binding globulin (CBG). The first goal of this study was to determine the organ distribution of the type III binding sites. Cytosol was prepared from isolated cells to avoid plasma contamination. Of the tissues examined, type III sites were found only in liver and kidney; sites were absent from thymocytes, IM-9 lymphocytes, adipocytes, and bone cells. The second goal of this study was to ascertain whether CBG is synthesized in liver and kidney. Liver and kidney slices were incubated in vitro and the concentration of type III sites was seen to rise in hepatic cytosol and incubating medium but not kidney. To verify the impression that liver was synthesizing and secreting CBG, the following experiments were performed: (a) To demonstrate that type III sites were CBG, steroid-binding profiles and migration on polyacrylamide gel electrophoresis were shown to be identical for hepatic type III sites and serum. (b) To indicate that the rise in type III sites was dependent on protein synthesis, it was shown that cycloheximide blocked the appearance of new type III sites. (c) To establish that the type III sites were being secreted, in situ liver perfusion experiments showed time-de-

This work was presented in part at the National Meeting of the American Federation for Clinical Research, San Francisco, Calif., April 1978.

Dr. Weiser was supported in part by the Howard Hughes Medical Institute Student Research Program. This work was done during Dr. Do's tenure as a postdoctoral fellow supported by a National Institutes of Health training grant 5T32 AM07217. Dr. Feldman is an Investigator with the Howard Hughes Medical Institute.

Received for publication 21 July 1978 and in revised form 12 October 1978. pendent release of new sites into the perfusate. In conclusion, liver synthesizes and secretes type III sites, a finding previously suspected but never proved. The presence of type III sites in kidney remains to be explained.

\section{INTRODUCTION}

Heterogeneity of glucocorticoid-binding proteins has been described in a variety of target tissues (1-4). We have previously demonstrated three distinct corticoid binders in rat kidney: type I, characterized by high affinity for aldosterone and low affinity for corticosterone, was felt to be the minerálocorticoid receptor (5); type II, characterized by high affinity for dexamethasone and corticosterone, was felt to represent the glucocorticoid receptor (6); and type III, characterized by high affinity for corticosterone but low affinity for dexamethasone (7), was not possible to classify according to function. The type III binding site was recognized to be indistinguishable in binding properties from plasma corticosteroid-binding globulin (CBG). ${ }^{1}$ In addition to classical glucocorticoid receptors (type II) several laboratories have described "CBG-like" binders in a variety of other tissues including liver (2, 3 ), brain and pituitary (8-9), muscle (10), lung (11), and uterus (12). We believe the CBG-like binders in other tissues and the type III binder in kidney may be the same but will use the designation type III binding in this paper to specify our experimental conditions. Because the binding properties of these cellular binders are virtually identical to CBG (7), we have been concerned about the difficulty in discriminating between a true intracellular molecule and extracellular fluid contamination of the tissues. At least for the kidney, we

\footnotetext{
${ }^{1}$ Abbreviations used in this paper: CBG, corticosteroidbinding globulin; KRB, Krebs-Ringer Bicarbonate; MEM, minimal essential medium.
} 
were able to demonstrate that the type III sites were intracellular with autoradiographic techniques (13).

The first aim of this study was to ascertain the organ distribution of these type III (CBG-like) binding sites (i.e., sites exhibiting a high affinity for corticosterone and low affinity for dexamethasone). We believed that knowing whether the binder was present in all tissues or restricted to only selected targets would have implications in a consideration of potential functions of this molecule. Once it was determined that, of the tissues examined, the binder was limited to liver and kidney, we turned our attention to the possibility that these organs might be sites of biosynthesis and secretion of plasma CBG, thus explaining the intracellular presence of type III binders. The liver has usually been considered the site of CBG synthesis but this fact has not been adequately documented. As will be detailed in this paper, the present data indicate that the liver does indeed synthesize and secrete type III binders which presumably represent CBG. This finding provides a basis for the intracellular localization of type III sites in liver. The presence of type III binding sites in the kidney remains to be explained.

\section{METHODS}

$\left[1,2-{ }^{3} \mathrm{H}\right]$ Corticosterone $(48 \mathrm{Ci} / \mathrm{mmol}),\left[1,3,4-{ }^{3} \mathrm{H}\right]$ dexametha-

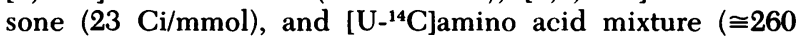
$\mathrm{mCi} / \mathrm{mmol}$ ) were purchased from New England Nuclear (Boston, Mass.). Unlabeled steroids (A grade) were obtained from Calbiochem-Behring Corp. (San Diego, Calif.). Conventional reagents were of analytical grade and were purchased from Sigma Chemical Co. (St. Louis, Mo.) unless otherwise specified. Sprague-Dawley, 160-200 g, male rats (Simonsen Laboratories, Gilroy, Calif.) were adrenalectomized before use and maintained on $0.9 \%$ saline drinking water and Purina chow pellets (Ralston Purina Co., St. Louis, Mo.) ad libitum. Rats were sacrificed by decapitation.

Preparation of isolated cells. All experiments employed adrenalectomized rats. Livers and kidneys were removed after the viscera were extensively perfused via the vena cava with $50 \mathrm{ml}$ of iced $\mathrm{Ca}^{++}$-free Krebs-Ringer bicarbonate (KRB) buffer (pH 7.4) to wash out blood and then with $20 \mathrm{ml}$ of $\mathrm{Ca}^{++}$. free KRB containing $1 \mathrm{mg} / \mathrm{ml}$ of crude collagenase (Worthington Biochemical Corp., Freehold, N. J.: CLS II). Each kidney was decapsulated, halved, and the papilla excised and discarded. The tissue was rinsed, blotted, and sliced $(275 \mu \mathrm{m}$ thickness) with a McIlwain tissue chopper (5-7). Slices were placed in a KRB solution with $1 \mathrm{mg} / \mathrm{ml}$ crude collagenase, $0.2 \%$ glucose, and $0.5 \%$ bovine serum albumin (Grand Island Biological Co., Grand Island, N. Y.) and incubated for $60 \mathrm{~min}$ at $37^{\circ} \mathrm{C}$ in a vigorously shaking water bath in a $95: 5 \%-\mathrm{O}_{2}$ : $\mathrm{CO}_{2}$ atmosphere. Cells were filtered through a $250 \mu \mathrm{m}$ nylon mesh, centrifuged at $100 \mathrm{~g}$, and resuspended three times with cold KRB. This yielded isolated hepatocytes and renal tubules with excellent viability assessed by trypan blue exclusion.

Adipocytes were obtained from epididymal fat pads which were diced into a $\mathrm{Ca}^{++}$-free $\mathrm{KRB}$ solution containing $3 \mathrm{mg} / \mathrm{ml}$ crude collagenase, $3 \mathrm{mM}$ glucose, and $4 \%$ BSA in a Nalgene flask (Nalge Co., Nalgene Labware Div., Rochester, N. Y.) (14). The tissue was incubated as above, washed twice with iced
KRB containing $1 \%$ bovine serum albumin and once with $\mathrm{KRB}$, and collected by flotation at $200 \mathrm{~g}$.

The thymus was removed, cleaned of connective tissue, and placed in cold $0.9 \%$ saline. Pieces of thymus were rinsed through a steel screen ( $100 \mu \mathrm{m}$ pore size) with iced incubating solution. Thymocytes were centrifuged at $250 \mathrm{~g}$ and washed once in $0.84 \% \mathrm{NH}_{4} \mathrm{Cl}$ to eliminate erythrocytes and twice with incubating solution.

The primary culture of bone cells from fetal rat calvaria has been described (15). Heat-inactivated calf serum was substituted in the procedure to avoid contamination with CBG. Monolayers were incubated with $1 \mathrm{mg} / \mathrm{ml}$ crude collagenase to remove extracellular collagen. The bone cells were centrifuged at $200 \mathrm{~g}$ and brought up twice in incubating solution.

Cultured IM-9 human lymphocytes (National Institutes of Health, Bethesda, Md.) were grown in a minimal essential medium (MEM) with Earle's salts (F-17, Grand Island Biological Co.) that included $10 \%$ heat-inactivated calf serum. Cells were collected from the suspension at $250 \mathrm{~g}$ and washed twice with incubating solution.

Preparation of tissue slices. Livers and(or) kidneys were perfused and sliced as described for isolated cell preparation, except the perfusion medium contained only iced $0.9 \%$ saline. Slices were carefully separated and rinsed several times with a cold KRB solution. For each sample, $1 \mathrm{~g}$ of slices was added to $4 \mathrm{ml}$ of sterile F-17 MEM (pH 7.4) with $25 \mathrm{mM}$ Hepes in a Nalgene flask. All flasks were incubated with continuous 95: $5 \%-\mathrm{O}_{2}: \mathrm{CO}_{2}$ at $37^{\circ} \mathrm{C}$ in a shaking water bath. At the end of the incubation, the flasks were placed on ice and the contents were homogenized with 20 strokes of a motor-driven Teflon (Du Pont Co., Wilmington, Del.) glass homogenizer. The homogenates were centrifuged at $50,000 \mathrm{~g}$ for $40 \mathrm{~min}$. The resulting high-speed supernate was stored at $-20^{\circ} \mathrm{C}$ for subsequent assay.

Binding assays. Type III binding was carried out by incubation in the presence of $52 \mathrm{nM}\left[{ }^{3} \mathrm{H}\right]$ corticosterone plus 10 -fold excess of aldosterone and dexamethasone to prevent isotope binding to type $I$ (mineralocorticoid receptor) and type II (glucocorticoid receptor) (5-7). Type II binding was carried out by incubation in the presence of $26 \mathrm{nM}\left[{ }^{3} \mathrm{H}\right]$ dexamethasone which binds only minimally to type III sites $(6,7)$. In both systems, nonspecific binding $(<20 \%$ of the total) was defined as that binding resistant to 100 -fold unlabeled steroid and was subtracted from total binding to give specific binding. Type II binding was performed immediately on fresh tissue, whereas type III binding could be performed on frozen material without loss of binding activity. Type II incubations were carried out at $0^{\circ} \mathrm{C}$ for $150 \mathrm{~min}$ and type III at $37^{\circ} \mathrm{C}$ for $30 \mathrm{~min}$. Pilot studies verified that the conditions employed measured peak steady-state levels of binding in both assays. In both systems, unbound steroid was removed by charcoal adsorption. Norite A $5 \%$ and dextran T70 $0.5 \%$ were prepared in a buffer of $10 \mathrm{mM}$ Tris- $\mathrm{HCl}$ and $1.5 \mathrm{mM}$ EDTA (pH 7.4). A onetenth volume of the dextran-coated charcoal solution was added to cytosol or serum, vortexed, and allowed to sit for $20 \mathrm{~min}$ at $0^{\circ} \mathrm{C}$. Charcoal was removed by centrifugation at $2,500 \mathrm{~g}$ for $10 \mathrm{~min}$ and the supernate radioassayed. The conditions of the assay gave similar results when samples were measured by Sephadex G-50 chromatography (Pharmacia Fine Chemicals, Div. of Pharmacia Inc., Piscataway, N. J.) (7). Protein was measured with Coomasie Brilliant Blue G-250 dye (Bio-Rad Laboratories, Richmond, Calif.) after the method of Bradford (16). Data are usually expressed per milligram of cytosol protein or where medium plus cytosol is used, per milligram of supernatant protein.

When the starting material was isolated cells, the washed cells were suspended in hypotonic buffer $(10 \mathrm{mM}$ Tris- $\mathrm{HCl}$, $1.5 \mathrm{mM}$ EDTA, $10 \mathrm{mM}$ monothioglycerol (pH 7.4), and lysed 
by sonication. A high-speed supernate $(50,000 \mathrm{~g}$ for $40 \mathrm{~min})$ was prepared from the lysate and used for binding studies. High-speed supernatant fractions from tissue slice experiments were thawed and diluted with hypotonic buffer to assay plasma CBG and(or) type III binding by similar procedures.

In whole cell binding studies, aliquots of cell suspensions were first counted electronically with a Coulter counter (Coulter Electronics Inc., Hialeah, Fla.). Cells were then incubated in F-17 MEM with appropriate concentrations of steroids for $30 \mathrm{~min}$ at $37^{\circ} \mathrm{C}$ in a $95: 5 \%-\mathrm{O}_{2}: \mathrm{CO}_{2}$ atmosphere while shaking. $1-\mathrm{ml}$ aliquots were then removed, placed in 1.5 $\mathrm{ml}$ micro test tubes, and centrifuged at $800 \mathrm{~g}$ for $1 \mathrm{~min}$. After two washes with $1 \mathrm{ml}$ of cold incubating solution, the cells were poured onto Whatman GF/A filter paper (Whatman, Inc., Clifton, N. J.) in a filtration manifold under vacuum. Filters were rinsed with $10 \mathrm{ml}$ of incubating solution which eliminated unbound steroids, and the dried filter paper was radioassayed. "Nonspecific" binding varied between 15 and $20 \%$ of total.

Cycloheximide experiments. The effect of cycloheximide on the incorporation of amino acids into proteins and the synthesis of CBG binding sites was measured in parallel experiments. After preincubations with various concentrations of cycloheximide for $90 \mathrm{~min}$, amino acid incorporation with a $\left[{ }^{14} \mathrm{C}\right]$ amino acid mixture was determined over the subsequent $120 \mathrm{~min}$. TCA ( $10 \%$ final concentration) was added to high-speed supernates of homogenates containing $\left[{ }^{14} \mathrm{C}\right] \mathrm{amino}$ acids. TCA precipitable protein was collected at $2,500 \mathrm{~g}$ for $10 \mathrm{~min}$ and washed twice with TCA (5\% final concentration). The precipitate was dissolved by incubation in $0.5 \mathrm{ml}$ of NCS tissue solubilizer (Amersham Corp., Arlington Heights, Ill.) for $24 \mathrm{~h}$ at $50^{\circ} \mathrm{C}$ and radioassayed. Parallel flasks of slices were treated similarly with cycloheximide and the type III binding site content of slices plus medium was measured.

Polyacrylamide gel electrophoresis experiments. Liver slices were incubated and aliquots of cytosol, incubation medium, and serum were labeled for type III sites as described above. In parallel experiments, unlabeled corticosterone was used and the medium pulsed for the final $60 \mathrm{~min}$ of a 4 -h incubation with $0.5 \mu \mathrm{Ci}$ of a $\left[{ }^{14} \mathrm{C}\right]$ amino acid mixture. Samples were then run on a slab gel electrophoresis apparatus (Pharmacia Fine Chemicals) at $2^{\circ} \mathrm{C}$ for $4 \mathrm{~h}$ at $6 \mathrm{~mA}$ sample. The gel was $7.5 \%$ polyacrylamide in a buffer of $0.05 \mathrm{M}$ Tris- $\mathrm{HCl}(\mathrm{pH} 8.5)$. The gels were stained for protein or sliced into $2.5-\mathrm{mm}$ fractions and the radioactivity determined.

\section{RESULTS}

Tissue distribution of type III binding: cytoplasmic assay. The distribution of type III binding sites in various tissues was examined. The selection of organs was based, in part, on our ability to prepare isolated cells and, thus avoid extracellular fluid contamination. Binding studies were performed on thymocytes, adipocytes, IM-9 lymphocytes, bone cells, hepatocytes, and renal tubules. As indicated in Fig. 1, with the exception of hepatocytes and renal tubules, none of these tissues exhibited cytoplasmic type III binders. Type II binding, was measured as a necessary condition for type III binding; the presence of the labile type II binding site implied that the relatively stable type III binder had not been destroyed during cell preparation or in the binding procedures. The number of cytoplasmic type

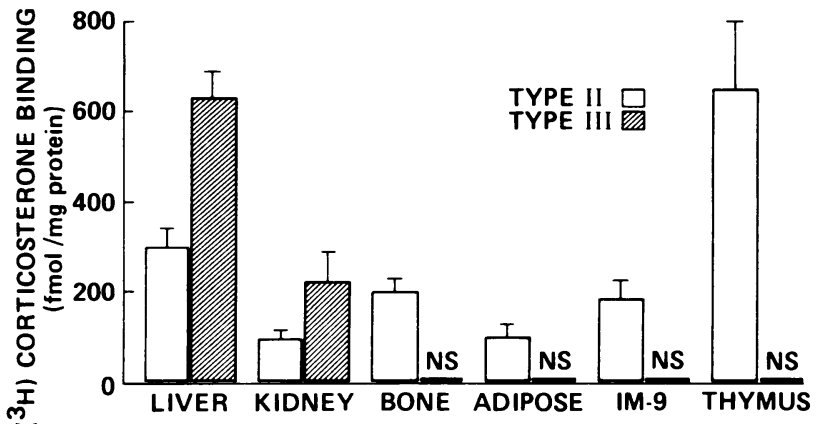

Figure 1 Glucocorticoid binding sites in cytosol prepared from isolated cells. Isolated cells were prepared as described in Methods. Cells were sonicated in hypotonic buffer and cytosol obtained. Binding studies were then performed with fresh cytosol; type II binding with $26 \mathrm{nM}\left[{ }^{3} \mathrm{H}\right]$ dexamethasone and type III binding with $52 \mathrm{nM}\left[{ }^{3} \mathrm{H}\right]$ corticosterone in the presence of 10 -fold unlabeled dexamethasone and aldosterone. Bound and free steroid were separated by charcoal. Nonspecific binding was $\cong 23 \%$ of total binding and was subtracted in each case. Results are expressed per milligram cytosol protein. NS indicates that the difference between total binding and nonspecific binding was not significant. Values shown are mean \pm SE. $n=6$ for liver and kidney and $n=4$ for the other organs.

III sites in renal tubules ( $212 \mathrm{fmol} / \mathrm{mg}$ cytosol protein) and in hepatocytes $(638 \mathrm{fmol} / \mathrm{mg}$ cytosol protein) was two to three times that of the type II value in the same tissue prepared with the same experimental procedure. In our hands, the concentration of type II receptors is always lower after isolated cell preparation than when cytosol is directly prepared from intact tissues.

Tissue distribution of type III binding: whole cell assay. It has been suggested that the subcellular location of CBG-like glucocorticoid binding may be on the plasma membrane of pituitary cells (17), or liver cells (18), or within the nucleus of hepatocytes (19). Because our experiments with high-speed supernates assayed mainly cytoplasmic corticosterone binders, we also used a whole-cell binding technique with isolated cells to include all subcellular components as potential sites of high affinity binding. As shown in Fig. 2, the results of whole cell binding procedures, like the cytoplasmic binding assays, showed type III binding only in kidney of the cell types examined. Because of variable and methodologically inconsistent results, we do not have confidence in similar experiments done with hepatocytes that gave exceptionally high values and adipocytes which, because they floated, were difficult to quantitatively transfer to the filters (data not shown).

Because the type III binder was not present in all tissues, we next turned our attention to the possibility that intracellular CBG-like material in liver and kidney might be the result of synthesis of plasma CBG by those organs. 


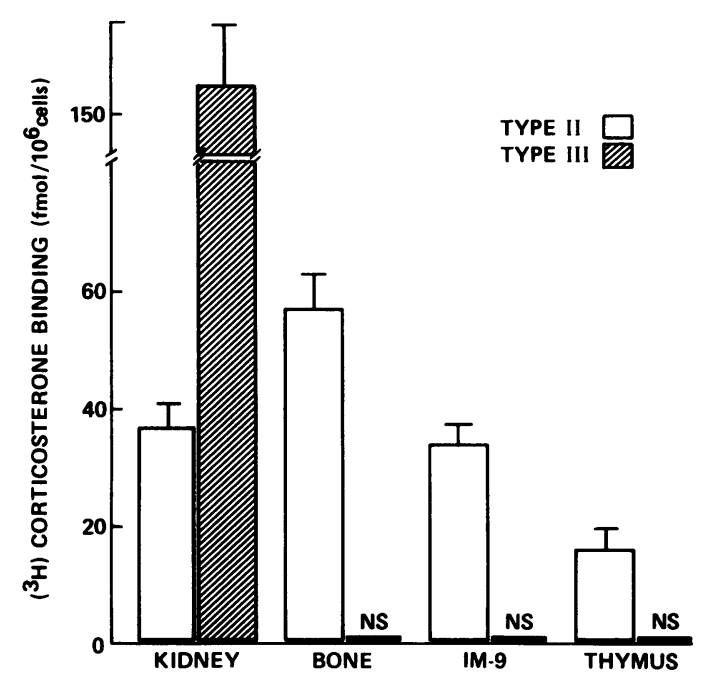

FIgUre 2 Glucocorticoid binding sites in whole cells. Isolated cells were prepared as described in Methods. Binding was performed by the whole cell technique; type II binding with $26 \mathrm{nM}\left[{ }^{3} \mathrm{H}\right]$ dexamethasone and type III binding with $52 \mathrm{nM}\left[{ }^{3} \mathrm{H}\right]$ corticosterone in the presence of 10 -fold unlabeled aldosterone and dexamethasone. Bound and free steroids were separated by washing cells on a filter. Nonspecific binding was $\cong 20 \%$ of total binding and was subtracted in each case. NS indicates that the difference between total and nonspecific binding was not significant. Values shown are mean $\pm \mathrm{SE}$. $n=4$.

Measurement of type III binding site production by liver and kidney slices. Liver and kidney slices were incubated for $240 \mathrm{~min}$ and the total number of type III binding sites was determined in tissue plus medium at hourly intervals. As shown in Fig. 3, the number of type III binding sites per milligram of supernatant

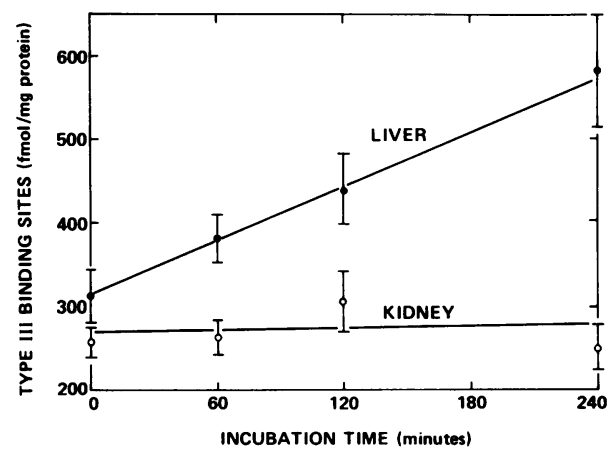

Figure 3 The effect of incubation time on the total number of type III binding sites in liver and kidney slices. Slices of liver and kidney were incubated at $37^{\circ} \mathrm{C}$ in a series of flasks. At the indicated time points, the tissue and medium in a given flask were homogenized and the high-speed supernate prepared and frozen. The concentration of total specific type III binding sites in cytosol plus medium was determined by the charcoal method and is expressed per milligram of supernatant protein. Each value is the mean \pm SE. $n=4$ experiments for both liver and kidney. protein was unchanged over time in kidney slices but linearly increased in liver slices from $309 \pm 32 \mathrm{fmol} / \mathrm{mg}$ protein at $0 \mathrm{~min}$ to $579 \pm 86 \mathrm{fmol} / \mathrm{mg}$ protein after 240 min of incubation at $37^{\circ} \mathrm{C}$. The almost doubling of the total number of type III sites per flask appeared to indicate that liver was a site of type III production.

Is the type III binder CBG? Anti-rat CBG antibody was not available to us for this study. In the absence of specific antibody, we employed the steroidal-binding properties as a means of characterizing the protein. The ability of a variety of steroids to compete for type III hepatic $\left[{ }^{3} \mathrm{H}\right]$ corticosterone binding sites was determined and the results compared to values for plasma CBG binding sites. The hepatic samples were taken from the bathing medium after 240-min liver slice incubations which contained $\cong 66 \%$ newly synthesized binding sites. The results are shown in Fig. 4. The order of affinities for $\left[{ }^{3} \mathrm{H}\right]$ corticosterone binding sites in both hepatic and plasma components was corticosterone $>$ cortisol $=$ progesterone $>$ aldosterone $>$ dexamethasone $>$ estradiol. Estradiol potentiated the binding of $\left[{ }^{3} \mathrm{H}\right]$ corticosterone by apparently occupying low affinity sites. The close correspondence between plasma CBG and liver slice high-speed supernatant binding is evidence that the newly produced binding sites in the liver are indistinguishable from plasma CBG binding sites.

To further substantiate that the proteins themselves are identical, polyacrylamide gel electrophoresis experiments were performed. The data indicate that plasma CBG and the hepatic protein from both cytosol and medium migrate in an identical fashion (Fig. 5). The nature of the slower migrating $\left[{ }^{3} \mathrm{H}\right]$ corticosterone binder in the medium is not clear. Taken with the binding data, these results strongly suggest type III binding sites represent CBG molecules.

Is the type III binder newly synthesized protein? Liver slices were treated with increasing concentrations of cycloheximide and $\left[{ }^{14} \mathrm{C}\right] \mathrm{amino}$ acid incorporation into TCA precipitable material assessed. As shown in Fig. 6B, a concentration of $20 \mu \mathrm{g} / \mathrm{ml}$ of cycloheximide blocked $\cong 90 \%$ of protein synthesis. As shown in Fig. 6A, this concentration of cycloheximide blocked $94 \%$ of the increase in type III binding as compared to untreated control slices. Lesser concentrations of cycloheximide caused comparably less inhibition of protein synthesis and comparably less blockage of type III production. The data suggest that the production of type III sites is dependent on protein synthesis.

Polyacrylamide electrophoresis data confirm that one of several protein peaks from medium and cytosol possessing newly incorporated $\left[{ }^{14} \mathrm{C}\right]$ amino acids comigrates with plasma CBG binding sites labeled with $\left[{ }^{3} \mathrm{H}\right]$ corticosterone (Fig. 7).

Is the type III binder secreted by liver in situ? In isolated in situ liver perfusion experiments, type III 


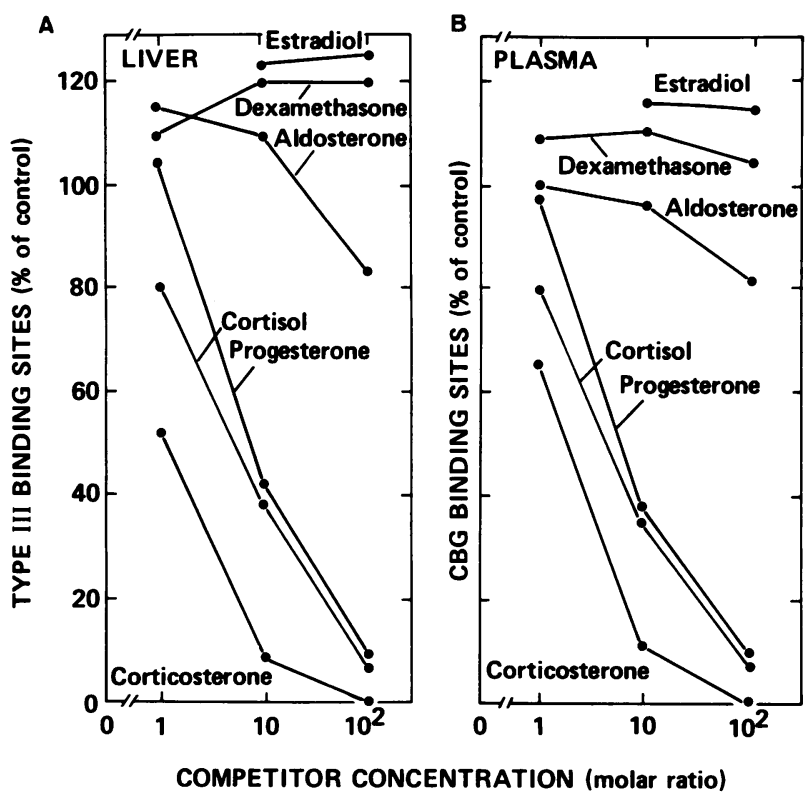

FIGURE 4 A comparison of the steroid binding profile of type III sites in liver cytosol and plasma. (A) Liver cytosol after 240 min slice incubation. (B) Plasma obtained from adrenalectomized rats. Cytosol or plasma was incubated with $2.6 \mathrm{nM}$ $\left[{ }^{3} \mathrm{H}\right]$ corticosterone plus increasing concentrations of the indicated unlabeled steroid for $30 \mathrm{~min}$ at $37^{\circ} \mathrm{C}$. Nonspecific binding was subtracted from all values. Total binding in the absence of competitor was taken as $100 \%$ and was $2,180 \mathrm{fmol} /$ $\mathrm{mg}$ plasma protein and $127 \mathrm{fmol} / \mathrm{mg}$ cytosol protein.

binding could be found in increasing amounts in the perfusate (Table I). Livers from intact rats were perfused in situ with a KRB buffer solution containing $38 \%$ erythrocytes and 3\% bovine serum albumin according to the method of Mortimore (20). The quantity of type III binding sites in the perfusate increased in a roughly linear fashion between 30 and $120 \mathrm{~min}$. The variability in the initial rate of secretion (0-30 min period) reflects the fact that the liver of rat 2 was better washed out before the perfusion was initiated. The high initial levels are, therefore, felt to represent washout of residual plasma CBG plus the secretion rate of the first $30 \mathrm{~min}$.

\section{DISCUSSION}

This work began as an attempt to elucidate the nature of the type III or CBG-like binding site in kidney. The organ distribution data (Figs. 1 and 2) indicate that type III binding is not universally distributed along with type II or classical glucocorticoid receptors but rather that its presence is restricted to certain organs. Of those organs tested, only the liver and kidney possessed the type III binding site. However, in our hands, all tissues appeared to possess the binder until extensive efforts at washing and cell isolation were undertaken to remove extracellular fluid. It is difficult to reconcile our findings with those of Amaral et al. (19) and Werthamer and colleagues (21) who found, by immunologic methods, a CBG-like protein in lymphocytes and liver nuclei.

The realization that the type III binder was limited to certain organs caused us to reconsider our previous position that the binder was related to hormone action $(7,13)$ and to examine other possibilities. Because the liver and kidney both synthesize many products and because the liver has long been suspected of being the site of CBG synthesis, we examined the hypothesis that type III intracellular binders might represent CBG synthesis. This does not appear to be the case for kidney (Fig. 3).

The following data indicate that the liver synthesizes and secretes CBG and that the type III binders represent intracellular CBG. First, the type III binders appear indistinguishable from CBG. A comparison of the type III steroid binding site and plasma CBG gives similar results (Fig. 4). Scatchard analysis has shown

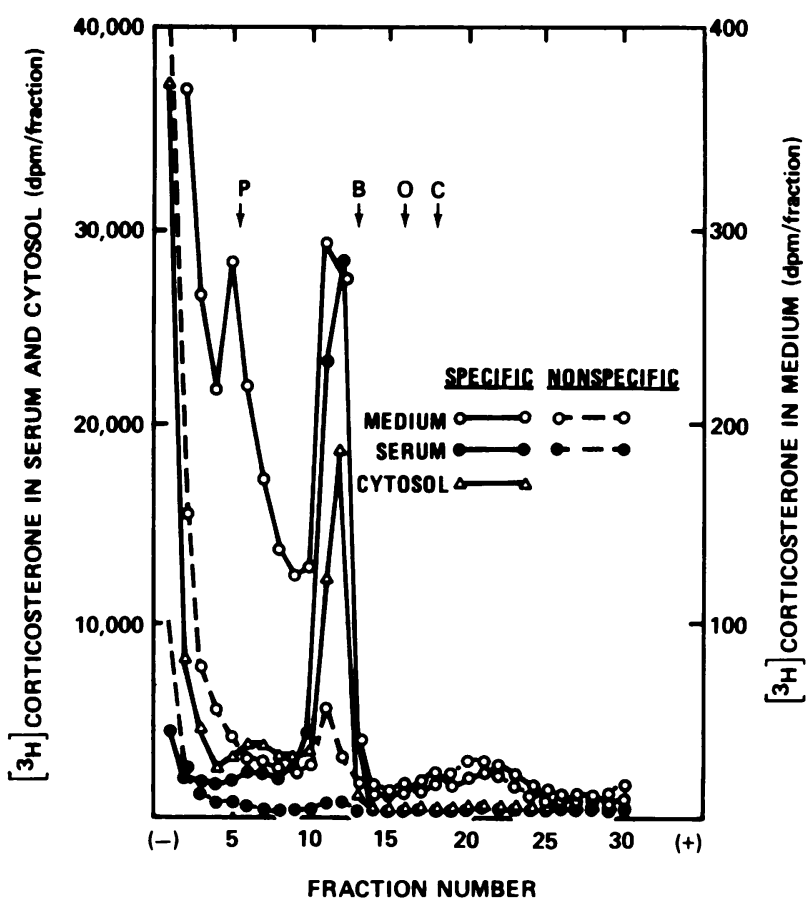

Figure 5 Polyacrylamide gel electrophoresis of $\left[{ }^{3} \mathrm{H}\right]$ corticosterone binders. Liver slices were incubated for $4 \mathrm{~h}$ at $37^{\circ} \mathrm{C}$. At the conclusion of the incubation, aliquots of liver cytosol and medium as well as serum were incubated with $26 \mathrm{nM}$ $\left[{ }^{3} \mathrm{H}\right]$ corticosterone \pm 250 -fold unlabeled corticosterone for 30 min at $37^{\circ} \mathrm{C}$. These samples were then subjected to slab gel electrophoresis on $7.5 \%$ polyacrylamide in a buffer containing $0.05 \mathrm{M}$ Tris- $\mathrm{HCl}(\mathrm{pH} 8.5)$ for $4 \mathrm{~h}$ at $2^{\circ} \mathrm{C}$ at $6 \mathrm{~mA} / \mathrm{sample}$. The standards and molecular weights are: $\mathrm{P}$, phosphorylase $\mathrm{b}$ $(94,000)$; B, bovine serum albumin $(67,000)$; O, ovalbumin $(43,000)$; and $C$, carbonic anhydrase $(30,000)$. 


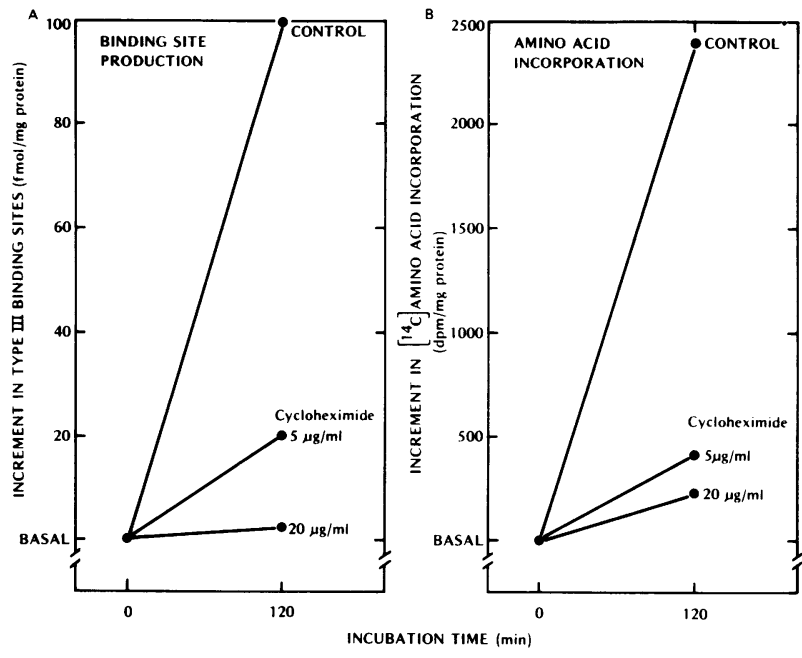

FIGURE 6 The effect of cycloheximide on type III binding site production and amino acid incorporation in liver slices. Slices were preincubated in cycloheximide for $90 \mathrm{~min}$. (A) Increment in type III binding site production. The binding sites represent tissue plus medium. The basal level was 214 $\mathrm{fmol} / \mathrm{mg}$ of supernatant protein. (B) Inhibition of amino acid incorporation into TCA precipitable protein. After a 90 -min preincubation in medium plus or minus cycloheximide, $\left[{ }^{14} \mathrm{C}\right]$ amino acids were added for the next $120 \mathrm{~min}$.

that both proteins possess the same affinity for $\left[{ }^{3} \mathrm{H}\right]-$ corticosterone (data not shown). Furthermore, electrophoresis on polyacrylamide gel shows identical mobility of plasma, cytosol, and medium $\left[{ }^{3} \mathrm{H}\right]$ corticosterone binders (Fig. 5). Previous studies showed multiple other properties in common (7).

Second, the liver appears to be synthesizing the binder. Support for this argument is found in studies showing a rise in type III sites over time (Fig. 3 ). $\left[{ }^{14} \mathrm{C}\right]-$ Amino acids are incorporated into a protein that comigrates with serum labeled with $\left[{ }^{3} \mathrm{H}\right]$ corticosterone (Fig. 7). Inhibition of the rise in type III binding by concentrations of cycloheximide that inhibit $\cong 90 \%$ of amino acid incorporation is further evidence that the rise in binding site content is dependent on protein synthesis.

Third, the liver secretes type III binders in vitro and in situ. In vitro, the liver slices exhibited a timedependent release of type III sites into the medium bathing the slices. This process was also inhibited by cycloheximide. Our initial studies using an in situ liver perfusion system, indicated a roughly linear secretion of type III binding sites into the perfusing medium (Table I).

Although the data indicate that the liver is synthesizing and secreting CBG, we cannot rule out the possibility that intracellular CBG plays an additional physiological role in liver. Because the kidney does not

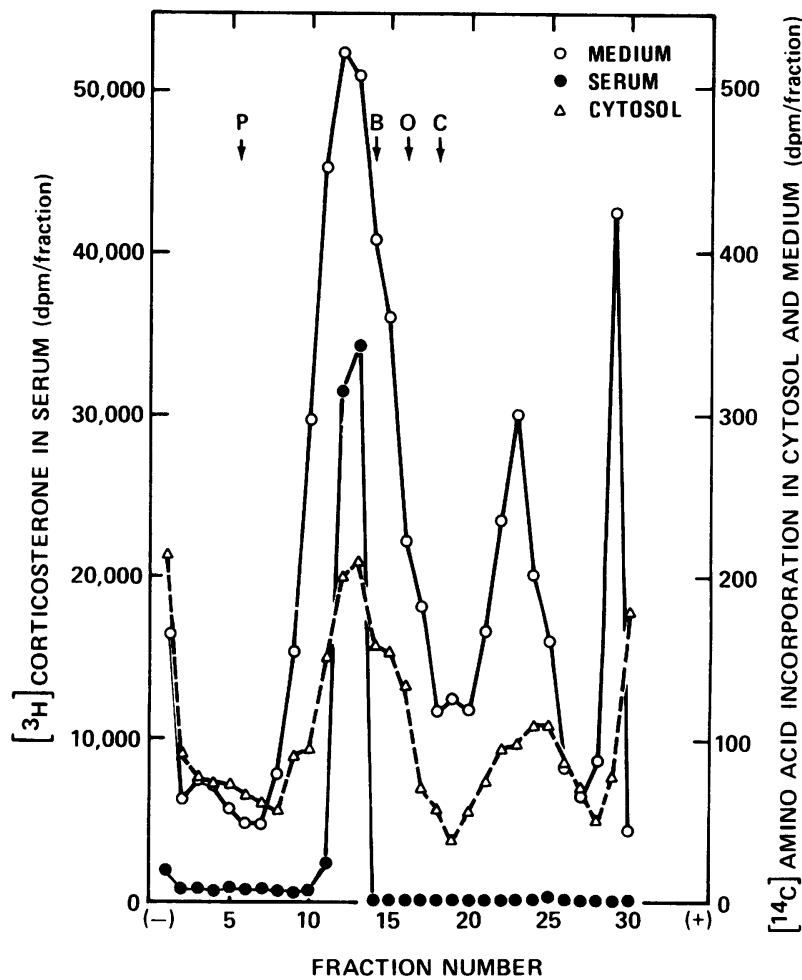

FIgURE 7 Polyacrylamide gel electrophoresis after $\left[{ }^{14} \mathrm{C}\right]-$ amino acid incorporation into hepatic cytosol. Liver slices were incubated for $4 \mathrm{~h}$ at $37^{\circ} \mathrm{C}$ in a medium that included $\left[{ }^{14} \mathrm{C}\right]$ amino acid mixture. At the conclusion of the incubation, aliquots of liver cytosol and medium as well as serum incubated with $\left[{ }^{3} \mathrm{H}\right]$ corticosterone were subjected to slab gel electrophoresis as described in the legend in Fig. 5.

TABLE I

Time-Course of CBG Secretion by In Situ Perfused Liver

\begin{tabular}{|c|c|c|c|c|}
\hline \multirow[b]{3}{*}{ Time } & \multicolumn{4}{|c|}{$\left[{ }^{3} \mathrm{H}\right]$ Corticosterone binding sites } \\
\hline & \multicolumn{2}{|c|}{ Rat 1} & \multicolumn{2}{|c|}{ Rat 2} \\
\hline & $\begin{array}{l}\text { Cumulative } \\
\text { secretion }\end{array}$ & $\begin{array}{l}\text { Incremental } \\
\text { secretion }\end{array}$ & $\begin{array}{c}\text { Cumulative } \\
\text { secretion }\end{array}$ & $\begin{array}{l}\text { Incremental } \\
\text { secretion }\end{array}$ \\
\hline $\min$ & \multicolumn{4}{|c|}{ pmol } \\
\hline $0-30$ & 112 & 112 & 54 & 54 \\
\hline $0-60$ & 153 & 41 & 89 & 35 \\
\hline $0-90$ & 184 & 31 & 135 & 46 \\
\hline $0-120$ & 236 & 52 & 179 & 44 \\
\hline
\end{tabular}

Intact rats underwent in situ liver perfusion with serum-free perfusate. Aliquots of perfusate were sampled at the indicated time points for $\left[{ }^{3} \mathrm{H}\right]$ corticosterone binding sites by the charcoal method. The first 30-min period represents some liver washout of plasma CBG in addition to the new secretion. The data is expressed as total picomoles secreted into the perfusion medium per unit time. 
appear to synthesize CBG, a role for the type III binder in that tissue remains to be determined.

The studies documenting CBG-like binders in other organs (8-12) have, to a variable degree, attempted to exclude extracellular fluid as a source of the binding protein. However, as has become apparent with binding systems for other steroid hormones, the exclusion of plasma contamination is a difficult problem. Alphafetoprotein, an important estrogen plasma binding protein in perinatal rats, must be carefully distinguished from the true intracellular estrogen receptor (22). Additionally, it is now believed that the widespread occurrence of 25-hydroxycholecalciferol binding protein in tissues is the result of plasma contamination (23). In this later case, the issue is more complex, as it appears that a tissue and a plasma component interact to yield the binding protein.

\section{ACKNOWLEDGMENTS}

We thank Dr. Carl Mondon for performing the perfusion experiments.

This work was supported by National Institutes of Health grant AM 18156.

\section{REFERENCES}

1. Feldman, D., J. W. Funder, and I. S. Edelman. 1972. Subcellular mechanisms in the action of adrenal steroids. Am. J. Med. 53: 545-560.

2. Koblinsky, M., M. Beato, M. Kalimi, and P. Feigelson. 1972. Glucocorticoid-binding proteins of rat liver cytosol. II. Physical characterization and properties of the binding proteins. J. Biol. Chem. 247: 7897-7904.

3. Litwack, G., R. Filler, S. A. Rosenfield, N. Lichtash, C. A. Wishman, and S. Singer. 1973. Liver cytosol corticosteroid binder II, a hormone receptor. J. Biol. Chem. 248: 74817486.

4. Agrawal, M. K., editor. 1977. Multiple molecular forms of steroid hormone receptors. Elsevier-North Holland, Inc., New York.

5. Funder, J. W., D. Feldman, and I. S. Edelman. 1973. The roles of plasma binding and receptor specificity in the mineralocorticoid action of aldosterone. Endocrinology. 92: $994-1004$.

6. Funder, J. W., D. Feldman, and I. S. Edelman. 1973. Glucocorticoid receptors in the rat kidney: the binding of tritiated-dexamethasone. Endocrinology. 92: 1004-1013.

7. Feldman, D., J. W. Funder, and I. S. Edelman. 1973. Evidence for a new class of corticosterone receptors in rat kidney. Endocrinology. 92: 1429-1441.
8. Koch, B., B. Lutz, B. Briaud, and C. Mialhe. 1976. Heterogeneity of pituitary glucocorticoid binding: evidence for a transcortin-like compound. Biochim. Biophys. Acta. 444: 497-507.

9. DeKloet, E. R., and B. S. McEwen. 1976. A putative glucocorticoid receptor and a transcortin-like macromolecule in pituitary cytosol. Biochim. Biophys. Acta. 421: 115-123.

10. Mayer, N., N. Kaiser, N. Milholland, and F. Rosen. 1975. Cortisol binding in rat skeletal muscle.J. Biol. Chem. 250: 1207-1211.

11. Giannopoulos, G. 1976. A comparative study of receptors for natural and synthetic glucocorticoids in fetal rabbit lung. J. Steroid. Biochem. 7: 553-559.

12. Milgrom, E., and E. E. Baulieu. 1970. Progesterone in uterus and plasma $I$. Binding in rat uterus $105,000 \mathrm{~g}$ supernatant. Endocrinology. 87: 276-287.

13. Strum, J. M., D. Feldman, B. Taggart, D. Marver, and I. S. Edelman. 1975. Autoradiographic localization of corticosterone receptors (Type III) to the collecting tubule of the rat kidney. Endocrinology. 97: 505-516.

14. Feldman, D., and D. Loose. 1977. Glucocorticoid receptors in adipose tissue. Endocrinology. 100: 398-404.

15. Chen, T. L., L. Aronow, and D. Feldman. 1977. Glucocorticoid receptors and inhibition of bone cell growth in primary culture. Endocrinology. 100: 619-628.

16. Bradford, M. M. 1976. A rapid and sensitive method for the quantitation of protein utilizing the principle of protein-dye binding. Anal. Biochem. 72: 248-254.

17. Koch, B., B. Lutz-Bucher, B. Briaud, and C. Mialhe. 1977. Glucocorticoid binding to plasma membranes of the adenohypophysis. J. Endocrinol. 73: 399-400.

18. Terayama, H., N. Okamura, and T. Suyemitsu. 1976. Epinephrine and corticoid receptors in plasma membranes of liver and hepatomas. In Control Mechanisms in Cancer. W. E. Criss, editor. Raven Press, New York. 83-97.

19. Amaral, L., K. Lin, A. J. Samuels, and S. Werthamer. 1974. Human nuclear transcortin: its postulated role in glucocorticoid regulation of genetic activity. Biochim. Biophys. Acta. 362: 332-345.

20. Mortimore, G. E. 1963. Effects of insulin on release of glucose and urea by isolated rat liver. Am. J. Physiol. 204: 699-704.

21. Werthamer, S., A. J. Samuels, and L. Amaral. 1973. Identification and partial purification of "transcortin-like" protein within human lymphocytes. J. Biol. Chem. 248: 6398-6407.

22. Chen, T. L., and D. Feldman. 1978. Distinction between alpha-fetoprotein and intracellular estrogen receptors: evidence against the presence of estradiol receptors in rat bone. Endocrinology. 102: 236-244.

23. Van Baelen, H., R. Bouillon, and P. DeMoor. 1977. Binding of 25-hydroxycholecalciferol in tissues. J. Biol. Chem. 252: 2515-2518. 